\title{
Group Dynamics and Student Cognitive Engagement in Class Tasks in Institutions of Higher Learning. - An Integrative Review
}

\author{
Muzaki Winnie $^{1 *}$, Dr. Nabukeera Madinah (PHD) ${ }^{2}$, Ejuu Godfrey (Assoc.Prof.) ${ }^{3}$ \\ ${ }^{1}$ PhD Student Kyambogo University Faculty of Education Department of Educational Psychology \\ ${ }^{2}$ Lecturer Kyambogo University Faculty of Arts and Social Sciences Department of History and Social Science \\ ${ }^{3}$ Senior Lecturer, Kyambogo University Faculty of Education Department of early Childhood Education \\ *Corresponding Author: Muzaki Winnie, PhD Student Kyambogo University Faculty of Education \\ Department of Educational Psychology, Uganda
}

\begin{abstract}
Lecturers in institutions of higher learning struggle to engage their students cognitively in class tasks. A lot of literature on strategies that enhance students' cognitive engagement include group work, however, some students do not benefit much from this strategy. The main question of this study was: How do group dynamics influence students' cognitive engagement during group work? The objectives of the study were: (1) to establish group dynamics that enhance cognitive engagement. (2) To identify group dynamics that prohibit student's cognitive engagement. (3) To establish proper management of group dynamics for cognitive engagement in institutions of higher learning. The study was an integrative review using online data bases such as JSTOR, ScieVerse Scopus EBSCO, SAGE Journal, Wiley Online between 2010 to 2020. Results of the study presented the influence of group dynamics on student's cognitive engagement in class tasks. Knowledge about positive and negative group dynamics when planning meaningful intellectual interactions in class tasks is relevant to teachers, lecturers, teacher trainers and curriculum designers. They should manage group dynamics well for effective cognitive engagement.
\end{abstract}

Key terms: Group Dynamics, Cognitive Engagement, Dysfunctional groups, Institutions of Higher Learning, Students, Lecturers

\section{BACKGROUND}

Students' cognitive engagement is an important element in the learning process as it enables them to actively participate in learning and facilitates understanding of the material at hand (1). Students increase their level of cognitive engagement when given freedom to select and manage their own learning(2). This therefore calls for lecturers to constantly strive for techniques that enhance active participation in cognitive tasks because they are aware that cognitive engagement is essential to academic success $(3)$

Cognitive engagement, as defined, involves seeking, interpreting, analyzing, and summarizing information; critiquing and reasoning through various opinions and arguments; and making decisions. Extended engagement in cognitive activities, especially those that require higher

order-thinking skills, is believed to produce useful learning(4). This implies that it can only be achieved when students persistently work on their intellectual tasks in groups.(5)posit that when students are in groups they investigate tasks collaboratively and eventually reach a solution.

(6)in their study about group work activities that engage students highlighted a number of activities that teachers can use to maximize students' interaction during group work. They included; creating something new like a written piece, investigating a question followed by reporting and critiquing among others.

This study is supported by the engagement theory described by(5)which emphasizes the importance of group tasks in enhancing students' cognitive engagement. In this case, students are organized in groups and given tasks to come up with solutions in a collaborative way. The theory is composed of three major concepts, that is, Relate - Create -Donate, whereby "Relate" suggests that cognitive engagement is most effective when students share knowledge in a group, listen to each other while 
observing social skills, "Create" implies that students develop solutions and agree on them, "Donate" means that solutions eventually contribute to the body of knowledge.

Group dynamics are described as psychological processes that occur within groups and how they influence the functioning of intellectual interactions among group members and between groups (7). Such processes include communication, leadership, cooperation, competition and so on.

Successful cognitive engagement depends on the success of group work, however, there are a number of undesirable behaviors that may prohibit its effectiveness(8). Working in groups and engaging in discussions could lead to either high or low feelings of autonomy, depending on the group dynamics. For instance, if there are members who are dominating the interaction, some maybe less engaged cognitively as opposed to a group that works well together (9). They also suggest that the level of autonomy is a characteristic to an activity or task and largely the degree to which students engage cognitively with that activity or task. This study consolidates literature on group dynamics that promote effective cognitive engagement among students in class tasks.

Although group work has a number of benefits, some studies indicate that it has got some shortcomings that teachers need to be aware of as they may affect students' engagement cognitively. For instance,(6)listed such shortcomings as, social loafing, disputes, individualized grading, students bemoaning among others. Teachers need to be aware of such group dynamics and how to manage them in order to have constant cognitive engagement among students in group tasks. The study also explores literature on such group dynamics that inhibit students' cognitive engagement in class tasks.

Several studies indicate that there is need to get familiar with proper management of group dynamics in group work in order to maximize interactions among group members(10). The role of techniques for enhancing group dynamics, resolving conflicts within groups for effective group work has also been highlighted in the study by (11).Despite all these studies there seem to be questions among teachers on how to manage dysfunctional groups(8). This study also analyzes literature on strategies for managing group dynamics for effective cognitive engagement.

\section{Methodology}

In this study, an integrative literature review was carried out to answer the following questions:

(1) What group dynamics enhance students' cognitive engagement during group work?

(2) What group dynamics affect students' cognitive engagement during group work?

(3) How can group dynamics be managed for effective cognitive engagement during group work?

The purpose of this integrative literature review was to establish the influence of group dynamics on students' cognitive engagement during group tasks in institutions of higher learning. The databases used were online such as JSTOR, EBSCO, SAGE Journal and Wiley Online. These databases were considered to have a complete collection of psychological interventions in the field of education.

\subsection{Inclusion Criteria for this Study was as Follows:}

Studies containing information about the group dynamics and / or the topic of group behaviours.

Studies with institutions of higher learning / equivalent to students as the subject. Studies reporting the results of evaluations of group dynamics that promote and those that prohibit cognitive engagement among students in class tasks. Studies reporting evaluations of proper management of group dynamics for effective students' cognitive engagement, Studies containing the following keywords: Group dynamics, cognitive engagement students, institutions of higher learning. The search was done using the search words listed in Table 1, while the combination of keywords is listed in Table 2.

Table1. Variation in key words

\begin{tabular}{|l|l|}
\hline Keyword(s) & Variation of keywords \\
\hline Group dynamics & Group behaviour \\
\hline Cognitive engagement & Intellectual or mental involvement \\
\hline Students & Students in institutions of higher learning \\
\hline Lecturers & instructors in institutions of higher learning \\
\hline Higher learning & Professional training \\
\hline
\end{tabular}


Group Dynamics and Student Cognitive Engagement in Class Tasks in Institutions of Higher Learning. An Integrative Review

ii. BOOLEAN search combination

\begin{tabular}{|l|l|}
\hline No & Boolean search combination \\
\hline 1 & $\begin{array}{l}\text { Group dynamics AND cognitive engagement OR mental engagement OR intellectual engagement AND } \\
\text { university student OR collegian OR college man }\end{array}$ \\
\hline 2 & $\begin{array}{l}\text { Group behaviour AND cognitive engagement OR mental engagement OR intellectual engagement } \\
\text { AND university student OR collegian OR college man }\end{array}$ \\
\hline 3 & $\begin{array}{l}\text { Group influence AND training OR instruction OR tutoring } \\
\text { AND student teacher OR university student }\end{array}$ \\
\hline
\end{tabular}

The integrative review employed a qualitative analysis using a topical method. Information was drawn from the articles using topics in line with the study objectives. The topics included the following:

(1) Group dynamics that enhance students' cognitive engagement among students during group work.

(2) Group dynamics that prohibit students' cognitive engagement during group work.

(3) Management of group dynamics for effective students' cognitive engagement during group work.

All used an integrative process as advanced by(12) to retrieve and filter literature and to undertake validity assessment, with reference to appropriate review guidelines. A detailed account of results for each objective was given after examination and synthesis.

\section{RESUlts AND DATA ANAlysiS}

The integrative literature review utilised 7 articles which were selected from data bases that included JSTOR, EBSCO, SAGE Journal, Wiley Online. The articles selected for the study were those published between 2010 to 2020 .

\begin{tabular}{|c|c|c|c|c|c|}
\hline Title & Year & Author & $\begin{array}{l}\text { Positive } \\
\text { Group } \\
\text { dynamics }\end{array}$ & $\begin{array}{l}\text { Negative } \\
\text { group } \\
\text { dynamics }\end{array}$ & $\begin{array}{l}\text { Proper } \\
\text { management } \\
\text { of group } \\
\text { dynamics }\end{array}$ \\
\hline $\begin{array}{l}\text { The } \\
\text { influence of } \\
\text { group } \\
\text { dynamics to } \\
\text { students' } \\
\text { creativity in } \\
\text { business } \\
\text { management } \\
\text { class. }\end{array}$ & 2019 & Liliana Dewi & $\begin{array}{l}\text {-The } \\
\text { characteristics of } \\
\text { the leader and } \\
\text { group members }\end{array}$ & $\begin{array}{l}- \\
\text { Problematic } \\
\text { leadership }\end{array}$ & $\begin{array}{l}- \text { Group } \\
\text { dynamics can } \\
\text { be improved by } \\
\text { developing } \\
\text { profiles such as } \\
\text { innovation; } \\
\text { ability to } \\
\text { implement } \\
\text { strategy with } \\
\text { programs, } \\
\text { evaluation; } \\
\text { initiative; desire } \\
\text { for } \\
\text { responsibility. } \\
\text {-The teacher } \\
\text { can deliver } \\
\text { lessons with the } \\
\text { help of group } \\
\text { leaders }\end{array}$ \\
\hline $\begin{array}{l}\text { Do They } \\
\text { Have to Like } \\
\text { It to Learn } \\
\text { from It? } \\
\text { Students' } \\
\text { Experiences, } \\
\text { Group } \\
\text { Dynamics, } \\
\text { and Learning } \\
\text { Outcomes in } \\
\text { Group } \\
\text { Research }\end{array}$ & 2019 & Renee A. Monson1 & $\begin{array}{l}\text {-Good leadership } \\
\text {-Balanced group } \\
\text { gender } \\
\text { Presence of one } \\
\text { or more high } \\
\text { achieving } \\
\text { students } \\
\text {-Group size } \\
\text {-Good } \\
\text { relationship } \\
\text { among group } \\
\text { members }\end{array}$ & $\begin{array}{l}\text { - } \\
\text { Problematic } \\
\text { leadership. } \\
\text {-Free riding } \\
\text { or social } \\
\text { loafing. } \\
\text {-Negative } \\
\text { relationships } \\
\text { among } \\
\text { students } \\
\text {-size of the } \\
\text { group }\end{array}$ & $\begin{array}{l}\text {-Active ongoing } \\
\text { support by the } \\
\text { instructor }\end{array}$ \\
\hline
\end{tabular}


Group Dynamics and Student Cognitive Engagement in Class Tasks in Institutions of Higher Learning. An Integrative Review

\begin{tabular}{|c|c|c|c|c|c|}
\hline Projects & & & & & \\
\hline $\begin{array}{l}\text { Effect of } \\
\text { group } \\
\text { dynamics on } \\
\text { performance } \\
\text { of first year } \\
\text { medical } \\
\text { students }\end{array}$ & 2020 & ChandrikaTeli1,*,NileshKate2 & & & $\begin{array}{l}\text {-Proper time } \\
\text { management } \\
\text {-Task } \\
\text { responsibility } \\
\text {-Regular } \\
\text { feedback by the } \\
\text { teacher } \\
\text {-Regular } \\
\text { feedback by } \\
\text { peers } \\
\text {-Good } \\
\text { communication } \\
\text { skills } \\
\text {-monitoring by } \\
\text { the teacher }\end{array}$ \\
\hline $\begin{array}{l}\text { Student } \\
\text { perception of } \\
\text { group } \\
\text { dynamics } \\
\text { predicts } \\
\text { individual } \\
\text { performance: } \\
\text { Comfort and } \\
\text { equity matter }\end{array}$ & 2017 & $\begin{array}{l}\text { Elli J. Theobald1, Sarah L. } \\
\text { Eddy2, Daniel Z. Grunspan, } \\
\text { Benjamin L. Wiggins1, } \\
\text { \&Alison J. Crowe1 }\end{array}$ & $\begin{array}{l}\text {-comfort } \\
\text {-working with a } \\
\text { friend. } \\
\text {-equity }\end{array}$ & $\begin{array}{l}\text {-Dominating } \\
\text { in a group }\end{array}$ & $\begin{array}{l}\text {-Establishing } \\
\text { group norms to } \\
\text { increase } \\
\text { comfort } \\
\text {-having many } \\
\text { opportunities to } \\
\text { perform group } \\
\text { work so that } \\
\text { students can get } \\
\text { to know each } \\
\text { other well to } \\
\text { increase } \\
\text { comfort in a } \\
\text { group } \\
\text {-Allowing } \\
\text { students to self- } \\
\text { select into } \\
\text { groups so that } \\
\text { they can choose } \\
\text { to work with } \\
\text { friends if they } \\
\text { wish. } \\
\text {-allowing social } \\
\text { connections } \\
\text { within groups } \\
\text {-the group } \\
\text { activity should } \\
\text { be complex to } \\
\text { allow interdependence } \\
\text { inter instructor/ } \\
\text {-the leader } \\
\text { group allow } \\
\text { should } \\
\text { social } \\
\text { interactions } \\
\text { within a group }\end{array}$ \\
\hline $\begin{array}{l}\text { Group } \\
\text { Dynamics and } \\
\text { Behavior }\end{array}$ & 2019 & Hüseyin Gençer & $\begin{array}{l}\text {-members' a to the } \\
\text { group. } \\
\text {-adherence } \\
\text { group norms to }\end{array}$ & $\begin{array}{l}\text { - "social } \\
\text { loafing } \\
\text { or "free } \\
\text { riding". } \\
\text {-weak } \\
\text { leadership. }\end{array}$ & $\begin{array}{l}\text {-formation of } \\
\text { group norms by } \\
\text { the leaders }\end{array}$ \\
\hline $\begin{array}{l}\text { When } \\
\text { groups don't } \\
\text { work: } \\
\text { Insights }\end{array}$ & 2018 & $\begin{array}{l}\text { Yunjeong Chang \& Peggy } \\
\text { Brickman }\end{array}$ & $\begin{array}{l}\text {-signing group } \\
\text { contracts. } \\
\text { - assigning roles } \\
\text {-equity }\end{array}$ & - & \\
\hline
\end{tabular}


Group Dynamics and Student Cognitive Engagement in Class Tasks in Institutions of Higher Learning. An Integrative Review

\begin{tabular}{|l|l|l|l|l|l|}
\hline $\begin{array}{l}\text { from } \\
\text { students }\end{array}$ & & & & & \\
\hline $\begin{array}{l}\text { Facilitation } \\
\text { of } \\
\text { collaborative } \\
\text { learning: } \\
\text { what works? }\end{array}$ & 2010 & $\begin{array}{l}\text { Chinthaka Balasooriya, } \\
\text { Sophie di Corpo\& } \\
\text { Nicholas J Hawkins }\end{array}$ & & $\begin{array}{l}\text {-dominant } \\
\text { students } \\
\text {-apathetic } \\
\text { students }\end{array}$ & $\begin{array}{l}\text {-allocation of } \\
\text { expert roles } \\
\text {-speaking } \\
\text { students } \\
\text { individually } \\
\text {-modeling } \\
\text { expected } \\
\text { behavior } \\
\text {-allocating time } \\
\text { for reflection at } \\
\text { the end of each } \\
\text { session } \\
\text {-increasing } \\
\text { motivation } \\
\text { small groups }\end{array}$ \\
\hline
\end{tabular}

\subsection{Group Dynamics that Enhance Students' Cognitive Engagement}

For effective cognitive engagement in group work among students in institutions of higher learning, a number of positive group dynamics were found. They included the following:

Characteristics of the group leader. Group leader characteristics were cited to be one of the positive group dynamics that can enhance group performance in terms of cognitive engagement. From the systematic review, 2 of the 7 journals indicated that group leader's traits have a positive influence in the direction of a group. In the study by (7), it was found out that group leader traits such as locus of control, communication, and self-efficacy positively influenced engagement among group members during a group task.(13) in his study: Group Dynamics and Behavior also indicated that leaders who follow group norms assure their members with confidence. He concluded that such leaders are always fair to every member of their groups.

Group composition. 1 of the 7 journals of the systematic review also indicated that group composition in terms of gender influence cognitive engagement during group tasks. In the study by(14)It was also found out that gender balance among group members especially in topics that were gendered created equal participation. Examples of such topics included; examining the effects of a recent sexual assault case and the impact of an abortion among women. Gender balance positively correlated with group achievement an indication of cognitive engagement.

Presence of one or more high achieving students. In the review it was also found that members of mixed ability in a group significantly influence cognitive engagement among group members. For example, in a study by (14), it was found out that groups that had mixed ability students during task execution performed better than their counterparts.

Good relationship among group member. 2 of the 7 journals in this systematic review reported good relationship among group members as one of the positive group dynamics that promote meaningful interactions among students in group tasks. This was found out by(15) in their study; Student perception of group dynamics predicts individual performance: Comfort and equity matter. Good relationships are important in a way that they encourage free participation and respect for one another's point of view.

Comfort. Research conducted by(15)indicated that comfort of students in groups that they are assigned to is very important as far as cognitive engagement in tasks is concerned. The study revealed that comfort was strongly positively correlated with students' performance as it provides student with freedom to participate or engage in the discussion with ease. Group members also feel secure to share ideas in groups where they are comfortable. They found out that students whose groups reported working with a friend scored higher on the post test. This was also an indication that meaningful interactions took place in that particular group.

Equity. The study by(15) indicated that groups that reported equal chances of participation performed quite better than their counterparts. The study also suggested that in order to increase equity, the group task should be highly structured to enable every member to participate, for instance, it should create a desire for every member to participate. 
Group size. Small groups were found to be a positive group dynamic as it was associated with vigorous mental interactions among its members. In the study by(14) it was found out that small groups of at least 1 to 7 engage in the exercise more than larger groups. This is because there are higher chances of each member to participate than in larger groups.

Adherence to group norms. Adherence to a group is characterized by members' desire to belong to a particular group(13).This group dynamic enables members to keep together and promotes cohesiveness among group members. Group norms are established by the group leader for purposes of binding the group together. However, the study showed that sometimes group members need to defy some group norms as they may slow down the performance of a group. It was also found out that leaders who follow group norms assure their members with confidence. Such leaders are always fair to every member of their group.

\subsection{Group Dynamics that Prohibit Students' Cognitive Engagement}

Dominant students. Research by(15)reported that groups that complained of dominators during engagement did not perform well. They were noted with less cognitive engagement among majority of its members. Dominators do not give chance to other members to contribute hence rendering them redundant.(8)also added that such students are either disruptive or highly enthusiastic (out spoken).

Problematic leadership. Most studies report problematic leadership as one of the negative group dynamics.(14), in her study found out that problematic leadership reduced participation among some members in groups whose leaders failed to control. This was also found out in the study by (7).

Free riding or social loafing. This was discovered in group assignments whose topics were gendered, such as, abortion and also in large groups (14). Large groups of more than five lead to less participation by some members in a group. In the study by (13), social loafing was also noted and it was concluded that individuals might opt to free-ride especially when a group is big.(7), also found out that free riding was one of their negative experiences among some students during the research project task in their study.(8) Also noted that such students may be quiet or disinterested due to lack of confidence and were termed as apathetic students.

Intergroup conflicts. Study findings from (13)indicate intergroup conflicts as a negative group dynamic. They established that intergroup conflicts are caused by competitive environments especially when one group is doing better that the other. This leads to less engagement in groups as it reduces attention of members on the task given.

Absenteeism In the study; When groups don't work: Insights from students by (16) it was found out that some group members dodge or absent themselves leaving the task for others to do.

\subsection{Strategies for Managing Group Dynamics}

In this integrative review, studies highlighted various strategies that instructors can utilize to manage group dynamics for effective cognitive engagement.

In the study by (14), instructors are advised to avoid constructing groups with a very large number as this limits participation and may lead to free riding. A group not beyond five members was recommended for positive results. A big group may also find it difficult to find time to meet due to diversity of schedules.

It was also suggested that instructors should avoid highly challenging topics that may create social loafing. They should give continuous guidance to students during group work which may also encourage cooperation and motivation among group members leading to meaning full participation. Instructors could do this by appraising members for the work being done or giving a mark to work done.

(15)in their study also suggested that instructors should endeavor to promote students comfort in groups as it was found to be a predictor of students' performance. They noted that it is one way of providing students with 'safety' for free expression of their ideas. They proposed several strategies that increase students' safety as; identifying group norms, regular group work in order for students to familiarize with each other, allowing social connections within groups, allowing students to choose groups in which they will be comfortable and so on, 
In addition to the above, they suggest that students should be assigned roles in groups so that every member can actively participate. It was also suggested that instructors should use prompts such as; explain your point, take turns to answer, what do you mean? and so on.

Allocation of roles to group members was one of the strategies to be employed in managing group dynamics. In the study by(17), it was suggested that distribution of tasks and feedback improve engagement among group members. They also noted that establishing group norms was very important as far as time management is concerned.

The group leader should allow social interactions within a group. In addition, instructors are argued to promote cooperation among intergroup in order to avoid conflicts (13). Clear instructions that guide the group task should be well spelt during a debriefing.

(8)also suggest that facilitators should use buddy system where students vary in strengths. This may help them to work together productively. They also suggest that students should be allocated time for reflection about the content at the end of the session. However, it would become tiresome if it is frequently used. Students with exceptional behavior should be spoken to individually and it should be done as soon as possible to prevent the behavior from escalating. Facilitators should also increase motivation in the small groups by use of feedbacks.

\section{CONClusion}

Cognitive engagement among students in group tasks can be effective with the knowledge of group dynamics and their management. Group dynamics such as group leader characteristics (innovation, locus of control, self-efficacy), group size, adherence to group norms and so on enhance students' cognitive engagement in group tasks. On the contrary, social loafing or free riding, intergroups conflicts, domineering are some of the group dynamics that may affect cognitive engagement during group work. For positive results, lecturers need to manage group behavior well as they utilize group work strategy.

\section{REFERENCES}

[1] Inggris PB. Student's Cognitive Engagement in Learning Process. 2016; 5(2):48-51.

[2] Shum KZ. Exploring the Facilitators and Barriers of Cognitive Engagement among Ninth Grade Students in Accelerated Curricula. 2017 ;( October).

[3] Wentzel KR. Students' relationships with teachers as motivational contexts. Handb Motiv Sch. 2009;

[4] Stoney \& Oliver 1999. IMEJ Article - Can Higher Order Thinking and Cognitive Engagement Be Enhanced with Multimedia.

[5] Miliszewska I, Horwood J. Engagement theory. ACM SIGCSE Bull. 2006; 38(1):158.

[6] Lynne N. Kennette and WH. Four Types of Group Work Activities to Engage Students.

[7] Dewi L. The Influence of Group Dynamics to Students' Creativity in Business Management Class of Universitas Ciputra. 2019 ; (30):713-8.

[8] Chinthaka Balasooriya \& Sophie di Corpo Nicholas J Hawkins. Facilitation of collaborative learning: what works? 2010.

[9] Rotgans JI, Schmidt HG. Cognitive engagement in the problem-based learning classroom. Adv Heal Sci Educ. 2011; 16(4):465-79.

[10] Berkel HJM Van, Dolmans DHJM 2006. The influence of tutoring competencies on problems, group functioning and student achievement in problem- based learning.

[11] Azer S. Facilitation of students' discussion in problem-based learning tutorials to create mechanisms : The use of five key questions Facilitation of Students' Discussion in Problem-based Learning Tutorials to Create Mechanisms : The Use of Five Key Questions. 2014 ;( June).

[12] Souza MT De, Carvalho R De. Integrative review : what is it? How to do it? Revisão integrativa : o que é e como fazer. 2010; 8:102-6.

[13] Gençer H. Group Dynamics and Behaviour. 2019; 7(1):223-9.

[14] Monson RA. Do They Have to Like It to Learn from It? Students' Experiences, Group Dynamics, and Learning Outcomes in Group Research Projects. 2019; Available from: https://doi.org/10.1177/0092055 X18812549

[15] Theobald EJ, Eddy SL, Grunspan DZ, Wiggins BL, Crowe J. Student perception of group dynamics predicts individual performance : Comfort and equity matter. 2017; 1-16. 
Group Dynamics and Student Cognitive Engagement in Class Tasks in Institutions of Higher Learning. An Integrative Review

[16] Chang Y, Brickman P. When Group Work Doesn't' Work: Insights from Students When Group Work Doesn't' Work : Insights from Students. 2018 ;(September).

[17] Teli C, Kate N. Effect of group dynamics on performance of first year medical students. 2020; 7(1):36-41.

Citation: Muzaki Winnie. "Group Dynamics and Student Cognitive Engagement in Class Tasks in Institutions of Higher Learning. - An Integrative Review” International Journal of Humanities Social Sciences and Education (IJHSSE), vol 7, no. 12, 2020, pp. 45-52. doi: https://doi.org/10.20431/2349-0381.0712006.

Copyright: (C) 2020 Authors. This is an open-access article distributed under the terms of the Creative Commons Attribution License, which permits unrestricted use, distribution, and reproduction in any medium, provided the original author and source are credited. 